\title{
Voltammetric Determination of Codeine on Glassy Carbon Electrode Modified with Nafion/MWCNTs
}

\author{
Robert Piech, Martyna Rumin, and Beata Paczosa-Bator \\ Faculty of Material Science and Ceramics, AGH University of Science and Technology, Mickiewicza 30, 30059 Cracow, Poland \\ Correspondence should be addressed to Beata Paczosa-Bator; paczosa@agh.edu.pl
}

Received 10 November 2014; Revised 13 January 2015; Accepted 13 January 2015

Academic Editor: Sibel A. Ozkan

Copyright (C) 2015 Robert Piech et al. This is an open access article distributed under the Creative Commons Attribution License, which permits unrestricted use, distribution, and reproduction in any medium, provided the original work is properly cited.

A glassy carbon electrode modified with a Nafion/MWCNTs composite is shown to enable the determination of codeine using differential pulse voltammetry in phosphate buffer of $\mathrm{pH}$ 3.0. At a preconcentration time of $15 \mathrm{~s}$, the calibration graph is linear in the $0.5 \mu \mathrm{M}\left(0.15 \mathrm{mg} \cdot \mathrm{L}^{-1}\right)$ to $15 \mu \mathrm{M}\left(4.5 \mathrm{mg} \cdot \mathrm{L}^{-1}\right)$ concentration range with a correlation coefficient of 0.998 . The detection limit at a preconcentration time of $120 \mathrm{~s}$ is as low as $4.5 \mu \mathrm{g} \cdot \mathrm{L}^{-1}$. The repeatability of the method at a $0.6 \mu \mathrm{g} \cdot \mathrm{L}^{-1}$ concentration level, expressed as the RSD, is $3.7 \%$ (for $n=5$ ). The method was successfully applied and validated by analyzing codeine in drug, human plasma, and urine samples.

\section{Introduction}

Codeine is a naturally occurring opium alkaloid. It is chemically known as 7,8-didehydro-4,5-epoxy-3-methoxy17-methylmorphinan-6-ol monohydrate [1] but is less potent than morphine, with a potency ratio of $1: 10$ [2]. Codeine is considered as a prodrug, metabolized to active compounds of morphine and codeine-6-glucuronide [3]. It is traditional choice for the treatment of mild and moderate pain [4] and is frequently recommended for pediatric use [5]. Moreover, codeine is widely used in cough cold syrup, but it would cause drug addiction and make mental damage to patient if abused [6]. Thus a sensitive, specific, fast, and cheap method of determining codeine is necessary for studying the presence of codeine in drugs and human body fluids.

The analytical methods most often used to determine codeine in various samples are high performance liquid chromatography [7-9], spectrophotometry [10, 11], gas chromatography [12], and capillary electrophoresis [13]. However, these methods are usually time consuming. Electrochemical methods for the determination of codeine as potentiometry and polarography are also reported $[14,15]$ but these methods are of rather low sensitivity. In the group of more sensitive methods as voltammetry various working electrodes such as glassy carbon electrode (the detection limit not shown) [16], Nafion/ruthenium oxide pyrochlore CME chemically modified electrode with the detection limit of $10 \mathrm{nM}$ [17], claymodified screen-printed carbon electrode (CMSPE) with the detection limit of $20 \mathrm{nM}$ [18], Prussian blue film modifiedpalladized aluminum electrode $(\mathrm{PB} / \mathrm{Pd} / \mathrm{Al})$ with the detection limit of $0.8 \mu \mathrm{M}$ [19], aluminum electrode modified with a thin layer of metallic palladium $(\mathrm{Pd} / \mathrm{Al})$ with the detection limit of $5 \mu \mathrm{M}[20,21]$, boron-doped diamond film electrode with the detection limit of $80 \mathrm{nM}$ [22], and singlewalled carbon nanotubes modified carbon ceramic electrode (SWCNTs/CCE) with the detection limit of $110 \mathrm{nM}$ [23] are used.

The aim of this work was to study the high sensitive determination of codeine by means of linear sweep voltammetry (LSV) and differential pulse voltammetry (DPV) with the use of glassy carbon (GC) electrode modified with Nafion/multiwalled carbon nanotubes (MWCNTs). The new procedure was examined and successfully used for the determination of a low codeine concentration in urine, human blood plasma, and medical products. Potential interference from selected metal ions, ascorbic acid, citric acid, and surface-active substances was checked. 


\section{Material and Methods}

2.1. Measuring Apparatus and Software. A multipurpose Electrochemical Analyzer M161 with the electrode stand M164 (MTM-ANKO, Poland) was used for all voltammetric measurements. The classical three-electrode quartz cell, volume $20 \mathrm{~mL}$, consists of a GC electrode (diameter $3 \mathrm{~mm}$, Mineral, Poland) modified with Nafion/MWCNTs as the working electrode, a double junction reference electrode $\mathrm{Ag} / \mathrm{AgCl} / \mathrm{KCl}(3 \mathrm{M})$ with replaceable outer junction $(3 \mathrm{M}$ $\mathrm{KCl}$ ), and a platinum wire as an auxiliary electrode. $\mathrm{pH}$ measurements were performed with a laboratory $\mathrm{pH}$-meter (N-512 elpo, Polymetron, Poland). Stirring was performed using a magnetic bar rotating at approximately $500 \mathrm{rpm}$. All experiments were carried out at room temperature. The MTM-ANKO EAGRAPH software enabled electrochemical measurements, data acquisition, and advanced processing of the results.

2.2. Chemicals and Glassware. All reagents used were of analytical grade. $\mathrm{KH}_{2} \mathrm{PO}_{4}$ and $\mathrm{K}_{2} \mathrm{HPO}_{4}$ were obtained from Merck and $\mathrm{H}_{3} \mathrm{PO}_{4}$ was obtained from CHEMAN (Poland). In measurements a $0.1 \mathrm{M}$ phosphate buffer solution $(\mathrm{pH}$ 3.0) was used (prepared using quadruply distilled water). Standard stock solutions of codeine $(0.01 \mathrm{M})$ were prepared by dissolving codeine phosphate (local source) in distilled water. Solutions with lower codeine concentrations were made by appropriate dilution of the stock solution. The multiwalled carbon nanotubes (purity $>95 \%$, diameter $40-60 \mathrm{~nm}$, and length 5-15 $\mu \mathrm{m}$ ) were obtained from Nanostructured \& Amorphous Materials Inc. (USA). Nafion 5 wt.\% solution in a mixture of lower aliphatic alcohols and water was purchased from Aldrich.

Prior to use, glassware was cleaned by immersion in a $1: 1$ aqueous solution of $\mathrm{HNO}_{3}$, followed by copious rinsing in distilled water.

2.3. Preparation of the Electrode. Prior to modifying the GC electrode was mechanically polished with $\mathrm{Al}_{2} \mathrm{O}_{3}(0.05 \mu \mathrm{m})$ and then rinsed and sonicated $5 \mathrm{~min}$ in distilled water. Next $10 \mathrm{mg}$ of MWCNTs was added to $10 \mathrm{~mL}$ ethanol and Nafion (final Nafion concentration $0.1 \%$ ) and then sonicated for 2 hours to obtain a homogenous suspension. The prepared GC electrode was coated with $10 \mu \mathrm{L}$ homogenous Nafion/MWCNTs and allowed evaporating the solvent at room temperature in the air. Nafion/MWCNTs GC electrode was conditioned in phosphate buffer $(\mathrm{pH}$ 3.0) and can be used for several measurements.

2.4. Standard Procedure of Measurements. The electrochemical behavior of the Nafion/MWCNTs glassy carbon modified electrode was investigated using cyclic voltammetry. The voltammograms were recorded in the potential range from 875 to $1425 \mathrm{mV}$. Before each registration scan the potential of $1450 \mathrm{mV}(2 \mathrm{~s})$ was applied to clean the surface of the electrode. The electrode conditioned in this way was used to determine codeine in the supporting electrolyte: $0.1 \mathrm{M}$ phosphate buffer
(pH 3.0) (total volume $10 \mathrm{~mL}$ ) contained in a quartz voltammetric cell. In the case of DP measurements the potential of the electrode was changed in the following sequence: cleaning potential $1350 \mathrm{mV}$ for $2 \mathrm{~s}$ and preconcentration potential $E_{\mathrm{acc}}=300 \mathrm{mV}$ for $t_{\mathrm{acc}}=20 \mathrm{~s}$. During the preconcentration step codeine was adsorbed while the solution was being stirred (ca. $500 \mathrm{rpm}$ ) using a magnetic stirring bar. Then, after a rest period of $5 \mathrm{~s}$ a differential pulse voltammogram was recorded in the anodic direction from 300 to $1350 \mathrm{mV}$. The other experimental parameters were as follows: step potential, $5 \mathrm{mV}$; pulse potential, $50 \mathrm{mV}$; time step potential, $40 \mathrm{~ms}$ (20 ms waiting $+20 \mathrm{~ms}$ sampling time). Measurements were performed in solutions not previously treated with deoxygenation. Quantitative measurements were performed using the standard addition procedure.

\subsection{Sample Preparation}

2.5.1. Urine and Human Blood Plasma. For DPV determination of codeine in urine, $250 \mu \mathrm{L}$ of the fresh sample was added directly into voltammetric cell with supporting electrolyte (total volume $10 \mathrm{~mL}$ ). In the case of human blood plasma, $50 \mu \mathrm{L}$ of the fresh plasma was added to the supporting electrolyte (total volume $10 \mathrm{~mL}$ ). The samples (originally drug-free) were spiked with codeine.

2.5.2. Tablet and Syrup. For the determination of codeine in tablet, 3 tablets ( $15 \mathrm{mg}$ codeine per tablet) were dissolved in $25 \mathrm{~mL}$ volumetric flask and additionally sonicated for $15 \mathrm{~min}$. Next $10 \mu \mathrm{L}$ of the sample was added to the voltammetric cell.

For the determination of codeine in syrup ( $15 \mathrm{mg}$ codeine per $10 \mathrm{~mL}$ syrup), $10 \mu \mathrm{L}$ of the syrup was added directly to the voltammetric cell.

\section{Results and Discussion}

3.1. Cyclic Voltammetry Studies. The influence of the scan rate $(v)$ on the peak current and peak potential at the GC electrode modified with Nafion/MWCNTs was investigated in the range of $10 \mathrm{mV} \mathrm{s}^{-1}$ to $500 \mathrm{mV} \mathrm{s}^{-1}$ (Figure 1). During the scan at $\mathrm{pH}$ of 3.0 in phosphate buffer the single anodic peak has appeared. The absence of reduction peak in the reverse step indicates the irreversibility of the electrode reaction.

The peak current versus square root of scan rate gave a straight line practically up to $500 \mathrm{mV} \mathrm{s}^{-1}$. The obtained linear regression equation is

$$
I_{p}=1.80 v^{1 / 2}+0.26[\mu \mathrm{A}], \quad r=0.997 .
$$

This suggests that the process of electrode reaction is controlled by diffusion of codeine.

The anodic peak potential was shifted in the positive direction with the increasing scan rate. The peak potential versus $\ln$ scan rate gave a straight line (Figure 2 ).

The obtained linear regression equation is

$$
E_{p}=28.4 \ln (v)+1060[\mathrm{mV}], \quad r=0.997 .
$$

Based on the theory for an irreversible electrode reaction [24] from the slope of $E_{p}$ versus $\ln (v), \alpha n=0.45$ could be obtained 


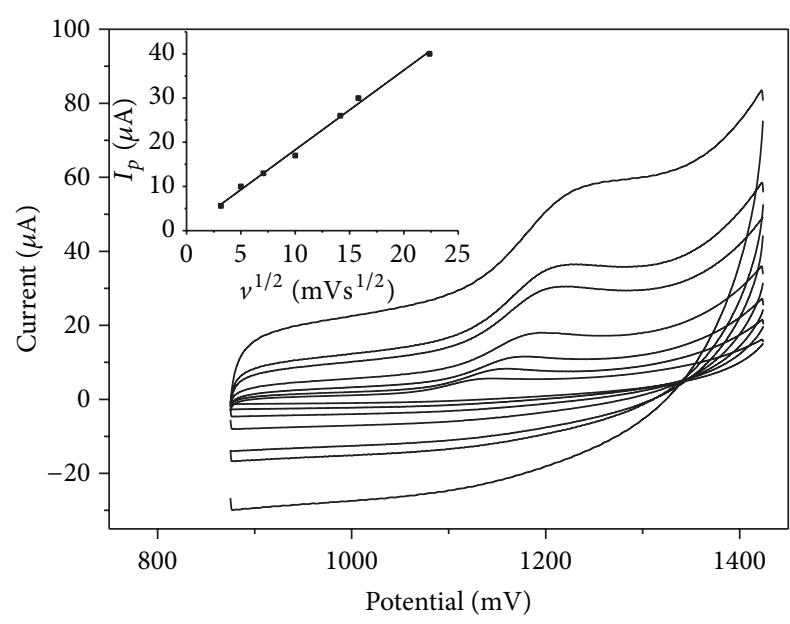

FIGURE 1: The cyclic voltammograms obtained for $50 \mu \mathrm{M}$ codeine at the GC electrode modified with $10 \mu \mathrm{L}$ Nafion/MWCNTs in $0.1 \mathrm{M}$ phosphate buffer ( $\mathrm{pH} 3.0$ ). Scan rate in the range from 10 to $500 \mathrm{mV} \mathrm{s}^{-1}$ (inner figure: dependence of the codeine peak current on square root of scan rate).

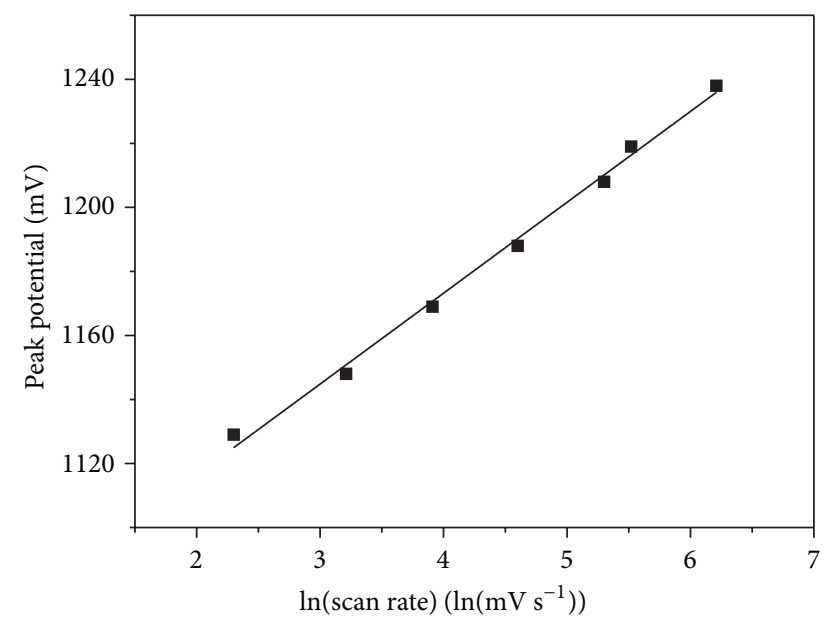

FIGURE 2: Dependence of the codeine peak potential on ln of scan rate in the range from 10 to $500 \mathrm{mV} \mathrm{s}^{-1}$ for $50 \mu \mathrm{M}$ codeine in $0.1 \mathrm{M}$ phosphate buffer ( $\mathrm{pH}$ 3.0).

and the number of the electron transfers for $\alpha$ assuming 0.5 could be calculated to be 1 .

\subsection{Influence of DPV Parameters Technique on Codeine Peak.} The important parameters of the DPV technique are pulse amplitude $(\Delta E)$, potential step amplitude $\left(E_{s}\right)$, waiting time $\left(t_{w}\right)$, and sampling time $\left(t_{s}\right)$. Consequently, these parameters were investigated. To optimize the conditions for codeine measurements, the following instrumental parameters were systematically varied: $\Delta E$ in the range $5-100 \mathrm{mV}$ (both positive and negative modes), $E_{s}$ in the range $1-7 \mathrm{mV}$, and $t_{w}$ and $t_{p}$ from 10 to $60 \mathrm{~ms}$.

The best results were obtained for the amplitude of $50 \mathrm{mV}$ (the peak current was $\sim 12 \mu \mathrm{A}$ for $10 \mu \mathrm{M}$ codeine, Figure 3 ). Higher pulse amplitude $(>50 \mathrm{mV})$ caused the growth of

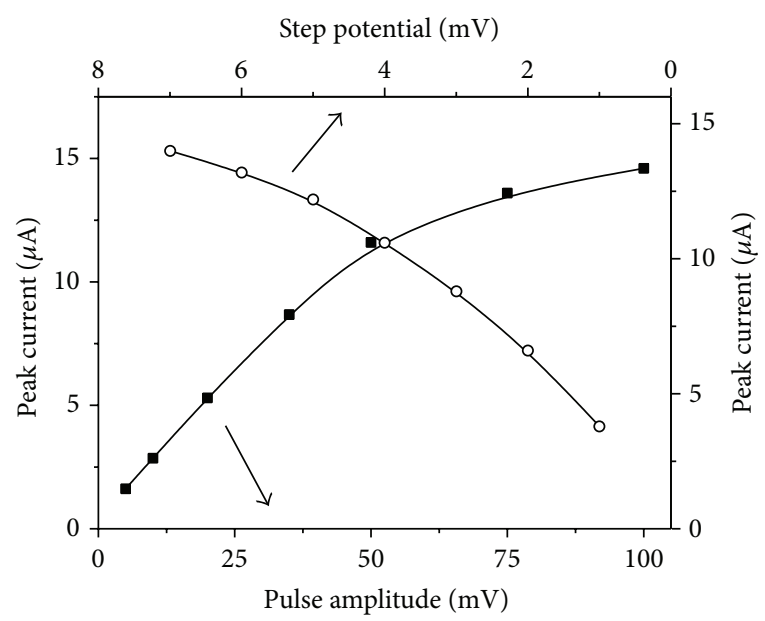

Figure 3: Dependence of the peak current on pulse amplitude in the range of 10 to $100 \mathrm{mV}$ and step potential in the range of 1 to $7 \mathrm{mV}$ for $10 \mu \mathrm{M}$ codeine in $0.1 \mathrm{M}$ phosphate buffer ( $\mathrm{pH}$ 3.0) volume of Nafion/MWCNTs $10 \mu \mathrm{L}$. Other instrumental parameters: $t_{w}, t_{s}$ $=20 \mathrm{~ms}$, preconcentration potential $300 \mathrm{mV}$, preconcentration time $20 \mathrm{~s}$, and stirring rate $500 \mathrm{rpm}$.

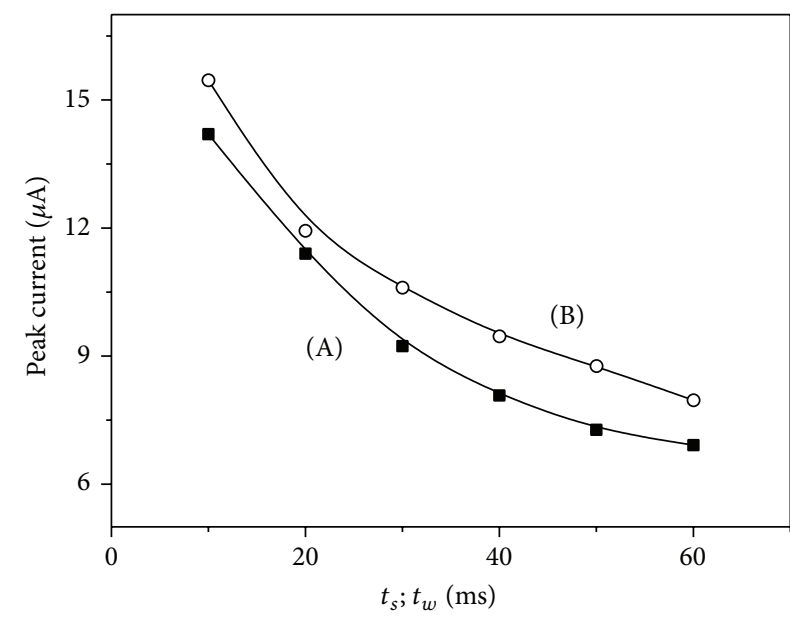

FIgURE 4: Dependence of the peak current on sampling (A) and waiting time (B) in the range of 10 to $60 \mathrm{~ms}$ for $10 \mu \mathrm{M}$ codeine in $0.1 \mathrm{M}$ phosphate buffer ( $\mathrm{pH} 3.0$ ) volume of Nafion/MWCNTs $10 \mu \mathrm{L}$. Other instrumental parameters: $\Delta E=50 \mathrm{mV}, E_{s}=5 \mathrm{mV}$, preconcentration potential $300 \mathrm{mV}$, preconcentration time $20 \mathrm{~s}$, and stirring rate $500 \mathrm{rpm}$.

the background current practically without increase of the peak current. For further work, the pulse amplitude of $50 \mathrm{mV}$ was applied.

Changes of the step potential cause influence on peak current. For a step potential equal to $1 \mathrm{mV}$ the peak current was $3.8 \mu \mathrm{A}$, and for a step potential of $7 \mathrm{mV}$ the peak current was $14 \mu \mathrm{A}$ (Figure 3 ). The step potential of $5 \mathrm{mV}$ was applied in further work (good relation codeine signal to background current).

The waiting time and sampling time were changed in the range from 10 to $60 \mathrm{~ms}$ (Figure 4). The best result was 


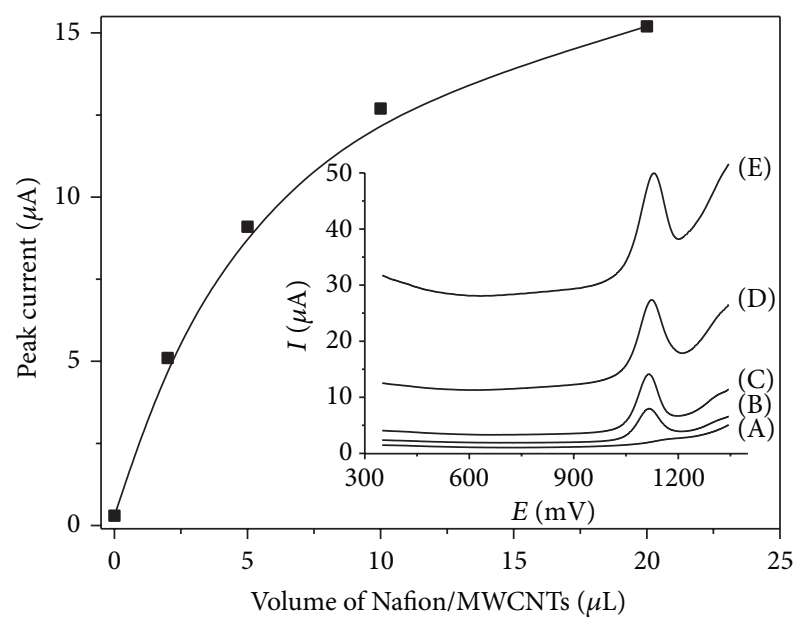

FIGURE 5: Dependence of the peak current on volume of Nafion/MWCNTs on GC electrode in the range of 0 to $20 \mu \mathrm{L}$ for $10 \mu \mathrm{M}$ codeine in $0.1 \mathrm{M}$ phosphate buffer ( $\mathrm{pH} 3.0$ ) and obtained voltammograms for (A) 0; (B) 2; (C) 5; (D) 10 ; (E) $20 \mu \mathrm{L}$ Nafion/MWCNTs. Instrumental parameters: $\Delta E=50 \mathrm{mV}, E_{s}=5 \mathrm{mV}$, and $t_{w}, t_{s}=20 \mathrm{~ms}$. Preconcentration potential $300 \mathrm{mV}$, preconcentration time $20 \mathrm{~s}$, and stirring rate $500 \mathrm{rpm}$.

obtained for waiting time and sampling time of $20 \mathrm{~ms}$ (best relation signal to background current), and this was the value chosen for further work.

3.3. Influence of the Volume of Nafion/MWCNTs. The mixture of Nafion/MWCNTs coating the GC electrode is necessary to obtain a high sensitive determination of codeine. The codeine peak current depends on the volume of Nafion/MWCNTs (Figure 5).

For bare GC electrode the codeine peak current was $0.3 \mu \mathrm{A}$. Presence and increase of the amount of Nafion/ MWCNTs on the GC electrode are accompanied by an increase of the codeine peak. The optimal volume of Nafion/ MWCNTs was $10 \mu \mathrm{L}$ (with the peak current reaching values about $12 \mu \mathrm{A}$ ). Higher volumes of Nafion/MWCNTs cause increase in a background current and worse repeatability of the codeine signal. The presence of Nafion/MWCNTs also had an influence on the peak potential. For bare GC electrode the DPV codeine peak potential was $1180 \mathrm{mV}$ and for modified electrode with Nafion/MWCNTs the codeine peak potential was $1125 \mathrm{mV}$. The negative shift of the peak potential suggests catalytic effect caused by Nafion/MWCNTs. For further work, the volume of $10 \mu \mathrm{L}$ was used.

3.4. Influence of Preconcentration Potential and Time on Codeine Peak. The influences of preconcentration potential and time are usually important factors on the sensitivity and detection limit of the stripping methods. Preconcentration potential for codeine determination in $0.1 \mathrm{M}$ phosphate buffer (pH 3.0) was investigated in the range from -200 to $900 \mathrm{mV}$. The experiment showed that the preconcentration potential has no influence on the codeine peak current. In the whole

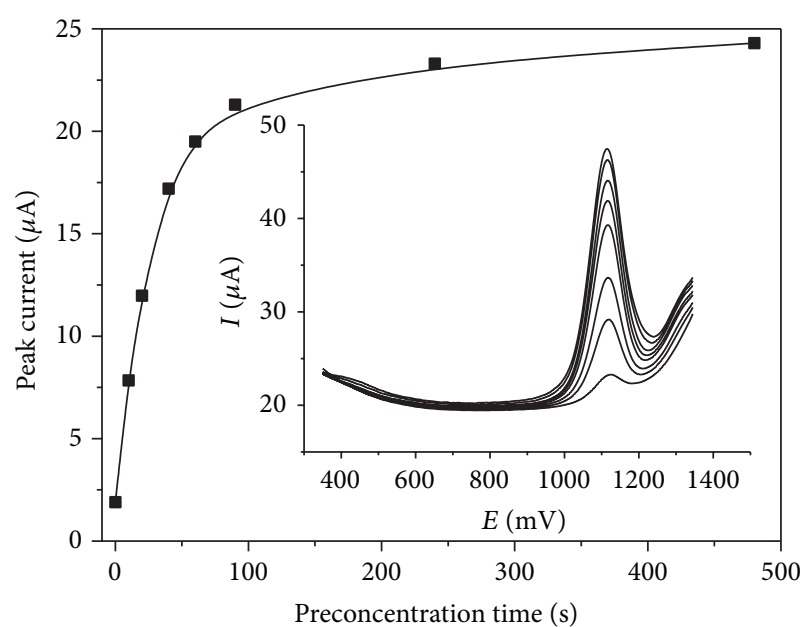

FIGURE 6: Dependence of the peak current on preconcentration time in the range from 0 to $480 \mathrm{~s}$ for $10 \mu \mathrm{M}$ codeine in $0.1 \mathrm{M}$ phosphate buffer ( $\mathrm{pH}$ 3.0) and volume of Nafion/MWCNTs $10 \mu \mathrm{L}$ and obtained voltammograms. All other conditions are as in Figure 5.

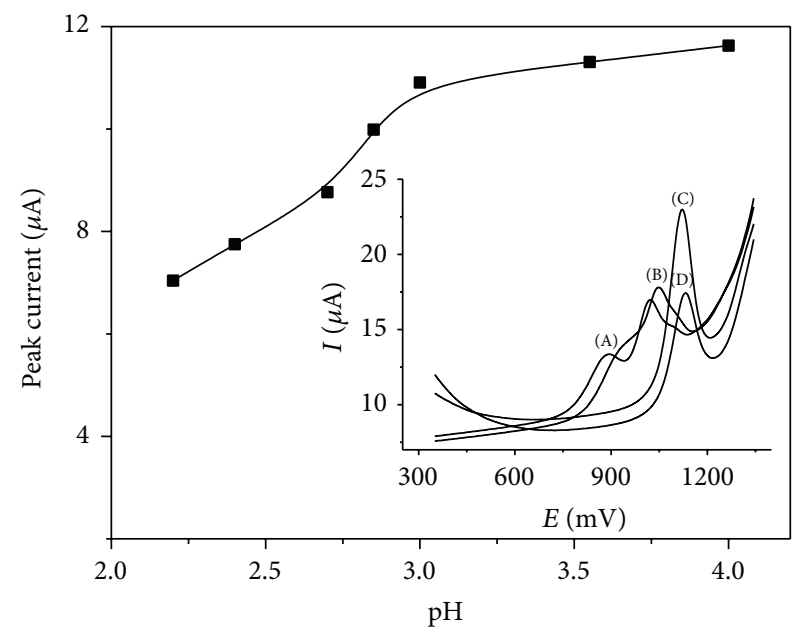

FIGURE 7: Dependence of the peak current on $\mathrm{pH}(2.2 ; 2.4 ; 2.7 ; 2.8 ; 3$; $3.6 ; 4.0)$ for $10 \mu \mathrm{M}$ codeine in $0.1 \mathrm{M}$ phosphate buffer and volume of Nafion/MWCNTs $10 \mu \mathrm{L}$ and obtained voltammograms for (A) 8.0; (B) 7.5 ; (C) 3.0 ; (D) $2.2 \mathrm{pH}$. All other conditions are as in Figure 5.

work arbitrary the $300 \mathrm{mV}$ preconcentration potential was used.

The changes in magnitude of the codeine current versus preconcentration time are presented in Figure 6.

The peak current increased with the increase of the preconcentration time from $1.9 \mu \mathrm{A}\left(t_{\mathrm{acc}}=0 \mathrm{~s}\right)$ to $24.3 \mu \mathrm{A}$ $\left(t_{\mathrm{acc}}=480 \mathrm{~s}\right)$. For a preconcentration time higher than $120 \mathrm{~s}$, practically no increase of the codeine peak current was observed. The codeine peak potential is independent of the preconcentration potential.

3.5. Influence of Electrolyte Composition and $\mathrm{pH}$ on Codeine Peak. The electrochemical oxidation of codeine has been studied in $0.1 \mathrm{M} \mathrm{KCl}(\mathrm{pH} 6.8), \mathrm{KNO}_{3}(\mathrm{pH} 6.9)$, acetate buffer 


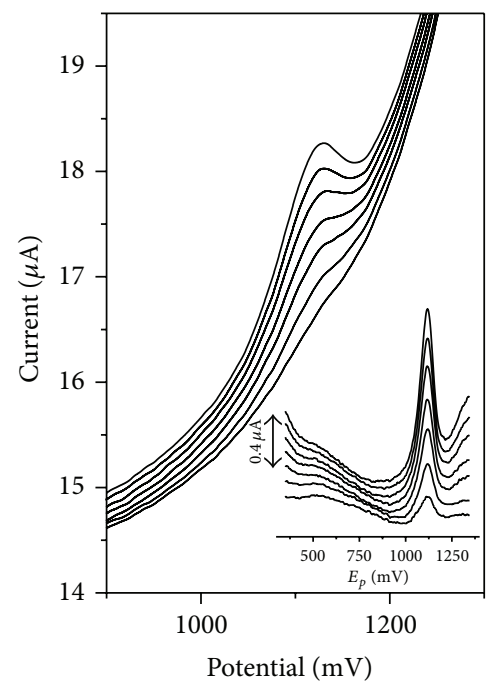

(a)

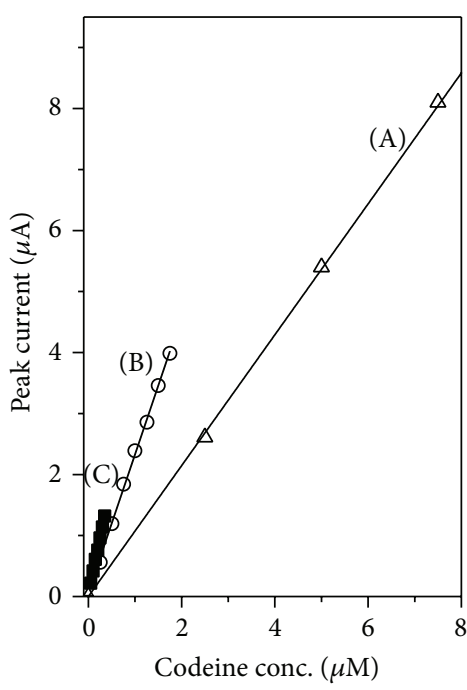

(b)

Figure 8: (a) The DP SV codeine calibration voltammograms for $0.05,0.1,0.15,0.2,0.25,0.3$, and $0.35 \mu \mathrm{M}$ codeine obtained for preconcentration time $120 \mathrm{~s}$ in $0.1 \mathrm{M}$ phosphate buffer ( $\mathrm{pH}$ of base electrolyte 3.0) and volume of Nafion/MWCNTs $10 \mu \mathrm{L}$ and (b) codeine calibration curves obtained for preconcentration times of (A) 15, (B) 60, and (C) $120 \mathrm{~s}$. All other conditions are as in Figure 5.

( $\mathrm{pH}$ 3.8), borate buffer ( $\mathrm{pH} 9.1)$, and phosphate buffers $(\mathrm{pH}$ in the range of 2.2 to 8.0 ). The best results were obtained in phosphates. Determination of codeine on GC electrode modified with Nafion/MWCNTs in phosphates requires an acidic condition in order to obtain a single peak. The shape of codeine peak depends strongly on the $\mathrm{pH}$. For the $\mathrm{pH}$ in the range of 8.0 to 7.5 triple codeine peak was observed and for the $\mathrm{pH}$ in the range of 7.0 to 4.8 double codeine peak was observed. Single, analytical, suitable, and well-shaped codeine signal was observed for the $\mathrm{pH}$ lower than 4.8 and this suggests that the anodic oxidation of codeine follows a complex mechanism that is $\mathrm{pH}$ dependent. The optimal $\mathrm{pH}$ for the quantity determination of small amounts of codeine was in the range from 4.0 to 3.0 (peak current reaching value about $12 \mu \mathrm{A}$ for $10 \mu \mathrm{M}$ codeine). More acidic conditions than pH 3.0 caused a decrease in the peak current; for example, for the $\mathrm{pH}$ of 2.2 the peak current was $7 \mu \mathrm{A}$ (Figure 7). For further measurements, the $\mathrm{pH}$ of 3.0 was applied.

3.6. Interference. The examined ions, such as $\mathrm{Ca}(\mathrm{II}), \mathrm{Mg}(\mathrm{II})$ in a 1000 -fold excess, $\mathrm{Zn}$ (II), $\mathrm{Mn}$ (II) in a 100 -fold excess, and $\mathrm{Pb}(\mathrm{II}), \mathrm{Cd}(\mathrm{II})$, and $\mathrm{Cu}(\mathrm{II})$ in a 2 -fold excess, did not interfere. Organic compounds such as caffeine, citric acid, and ascorbic acid in a 20 -fold excess and glucose $25 \mathrm{mg} \cdot \mathrm{L}^{-1}$ did not interfere.

The surface-active compounds are usually a source of strong interference in voltammetric methods. A nonionic surface-active compound (Triton X-100) was investigated in this respect. For $0.25 \mathrm{mg} \cdot \mathrm{L}^{-1}$ of Triton X-100 concentration, no suppression of the signal was observed. Higher concentration of Triton X-100 caused suppression of the signal, for example, for $2.5 \mathrm{mg} \cdot \mathrm{L}^{-1}$ of Triton X-100 by $50 \%$ and for $6 \mathrm{mg} \cdot \mathrm{L}^{-1}$ of Triton X-100 by $70 \%$.
3.7. Analytical Performance. The DP SV voltammograms of codeine for the $0.05-0.35 \mu \mathrm{M}$ concentration range and preconcentration time of $120 \mathrm{~s}$ are presented in Figure 8.

The detection limit obtained for short preconcentration time (15 s) was $130 \mathrm{nM}$ with the linearity up to $15 \mu \mathrm{M}$ (slope of the regression line was $1.02 \pm 0.03\left(\mu \mathrm{A} \cdot \mu \mathrm{M}^{-1}\right)$, intercept $0.21 \pm 0.23 \mu \mathrm{A}$, and correlation coefficient 0.998 ). A longer preconcentration time results in a lower detection limit (e.g., when the preconcentration time of $60 \mathrm{~s}$ was used during the measurement the detection limit was $22 \mathrm{nM}$, and for the preconcentration time of $120 \mathrm{~s}$ the detection limit was $14 \mathrm{nM})$.

The slopes for regression lines were $\left(\mu \mathrm{A} \cdot \mu \mathrm{M}^{-1}\right) 2.27 \pm$ 0.02 and $3.67 \pm 0.05$, intercepts $(\mu \mathrm{A}) 0.21 \pm 0.22$ and $0.04 \pm$ 0.03 , and the correlation coefficients 0.996 and 0.997 for preconcentration times of 60 and $120 \mathrm{~s}$, respectively. The linearity was up to $1.75 \mu \mathrm{M}\left(t_{\mathrm{acc}}=60 \mathrm{~s}\right)$ and $0.5 \mu \mathrm{M}\left(t_{\mathrm{acc}}=\right.$ $120 \mathrm{~s})$.

To validate the method the urine, human plasma, and drugs were investigated.

The samples, spiked with codeine, were analyzed according to the described procedure using the GC electrode modified with Nafion/MWCNTs. Determinations of codeine were performed using the standard addition method (three additions of the standard solution). Results from codeine determination are presented in Table 1 . The recovery of codeine ranged from 92 to $105 \%$. The analytical usefulness of the presented method for the determination of codeine in the samples was confirmed.

\section{Conclusions}

The presented DPV method for the electrochemical determination of codeine using a GC electrode modified with Nafion/MWCNTs allows determining codeine at trace level, 
TABLE 1: Results of codeine determination in various samples.

\begin{tabular}{lcccc}
\hline $\begin{array}{l}\text { Codeine } \\
\text { added }\end{array}$ & $\begin{array}{c}\text { Urine } \\
(\mathrm{mg} / \mathrm{L})\end{array}$ & $\begin{array}{c}\text { Human } \\
\text { plasma } \\
(\mathrm{mg} / \mathrm{L})\end{array}$ & $\begin{array}{c}\text { Syrup } \\
(\mathrm{mg} / 10 \mathrm{~mL})\end{array}$ & $\begin{array}{c}\text { Tablet }^{2} \\
\left(\mathrm{mg} / \mathrm{tablet}^{2}\right.\end{array}$ \\
\hline 0 & 0 & 0 & $15.5 \pm 0.7$ & $15.3 \pm 0.4$ \\
\hline $0.15 \mathrm{mg} / \mathrm{L}$ & $\begin{array}{c}0.144 \pm 0.009 \\
(96)\end{array}$ & $\begin{array}{c}0.138 \pm 0.012 \\
(92)\end{array}$ & - & - \\
\hline $0.6 \mathrm{mg} / \mathrm{L}$ & $\begin{array}{c}0.632 \pm 0.027 \\
(105)\end{array}$ & $\begin{array}{c}0.57 \pm 0.03 \\
(95)\end{array}$ & - & - \\
\hline $15 \mathrm{mg}$ & - & - & $\begin{array}{c}31.4 \pm 1.1 \\
(103)\end{array}$ & $\begin{array}{c}30.9 \pm 0.9 \\
(102)\end{array}$ \\
\hline
\end{tabular}

${ }^{1}$ Product declared $15 \mathrm{mg} / 10 \mathrm{~mL}$.

${ }^{2}$ Product declared $15 \mathrm{mg} /$ tablet.

TABLE 2: Voltammetric detection of codeine reported at various electrodes.

\begin{tabular}{lccc}
\hline Electrode & Linear range & Detection limit & Reference \\
\hline CME & $0-32 \mu \mathrm{M}$ & $10 \mathrm{nM}$ & {$[17]$} \\
CMSPE & $2.5-45 \mu \mathrm{M}$ & $20 \mathrm{nM}$ & {$[18]$} \\
$\mathrm{PB} / \mathrm{Pd} / \mathrm{Al}$ & $2-30 \mu \mathrm{M}$ & $0.8 \mu \mathrm{M}$ & {$[19]$} \\
$\mathrm{Pd} / \mathrm{Al}$ & $0.1-3 \mathrm{mM}$ & $5 \mu \mathrm{M}$ & {$[20]$} \\
$\begin{array}{l}\text { Boron-doped } \\
\text { diamond }\end{array}$ & $0.1-60 \mu \mathrm{M}$ & $80 \mathrm{nM}$ & {$[22]$} \\
$\begin{array}{l}\text { SWCNTs/CCE } \\
\text { Nafion/MWCNTs } \\
\left(t_{\text {acc }}=120 \mathrm{~s}\right)\end{array}$ & $0.2-230 \mu \mathrm{M}$ & $0.11 \mu \mathrm{M}$ & {$[23]$} \\
\hline
\end{tabular}

in concentrations as low as $14 \mathrm{nM}\left(4.5 \mu \mathrm{g} \cdot \mathrm{L}^{-1}\right)$, calculated according to [25] for a preconcentration time of $120 \mathrm{~s}$. The reproducibility of the method is very good; that is, when measured as RSD it is 3.7\%. Acceptable recovery (92-105\%) shows that the method can be used for the determination of codeine in drugs and human body fluids.

The preparation of GC electrode modified with Nafion/MWCNTs is very simple, short, and economically acceptable. The obtained results confirm that method may be used in out-of-laboratory systems.

Voltammetric responses of Nafion/MWCNTs in terms of linear range and detection limits were compared to the other electrodes reported in the literature (Table 2).

\section{Conflict of Interests}

The authors declare that there is no conflict of interests regarding the publication of this paper.

\section{Acknowledgment}

This work was supported by The National Centre for Research and Development (NCBiR) within a framework of LIDER program (no. LIDER/31/7/L-2/10/NCBiR/2011).

\section{References}

[1] J. E. F. Reynolds, Martindale the Complete Drug Reference, The Royal Pharmaceutical Publications Department, London, UK, 31st edition, 1996.

[2] S. L. Wallenstein, R. W. Houde, and J. W. Bellwille, "Relative potency and effectiveness of codeine and morphine," Federation Proceedings, vol. 20, article 311, 1961.

[3] S. C. Armstrong and K. L. Cozza, "Pharmacokinetic drug interactions of morphine, codeine, and their derivatives: theory and clinical reality, Part II," Psychosomatics, vol. 44, no. 6, pp. 515-520, 2003.

[4] D. G. Williams, D. J. Hatch, and R. F. Howard, "Codeine phosphate in paediatric medicine," British Journal of Anaesthesia, vol. 86, no. 3, pp. 413-421, 2001.

[5] N. L. Schether, C. B. Berde, and M. Yaster, Pain in Infans, Children, and Adolescents, Williams \& Wilkins, Baltimore, Md, USA, 1st edition, 1993.

[6] S. Panda, A. Chatterjee, C. Saha, S. Bhattacharjee, S. K. Bhattacharya, and A. S. A. Quader, "Morphine and codeine in the water extract of poppy straw: a traditional substitution used by drug users in Calcutta, India," International Journal of Drug Policy, vol. 15, no. 3, pp. 214-216, 2004.

[7] S. Süzen, C. Akay, and S.. Cevheroglu, "Simultaneous determination of guaiphenesin and codeine phosphate in tablets by high-performance liquid chromatography," Farmaco, vol. 54, no. 10, pp. 705-709, 1999.

[8] V. Maslarska and J. Tencheva, "Simultaneous determination and validation of paracetamol and codeine phosphate in pharmaceutical preparation by RP-HPLC," International Journal of Pharmacy \& Pharmaceutical Sciences, vol. 5, no. 2, pp. 417-419, 2013.

[9] E. Haffen, G. Paintaud, M. Berard, C. Masuyer, Y. Bechtel, and P. R. Bechtel, "On the assessment of drug metabolism by assays of codeine and its main metabolites," Therapeutic Drug Monitoring, vol. 22, no. 3, pp. 258-265, 2000.

[10] M. A. Elsayed, S. F. Belal, A.-F. M. Elwalily, and H. Abdine, "Spectrophotometric determination of acetaminophen, salicylamide and codeine phosphate in tablets," Analyst, vol. 104, pp. 620-625, 1979.

[11] V. N. Edebi, B. U. Ebeshi, and E. Anganabiri, "Simultaneous assay of codeine phosphate and diphenhydramine hydrochloride in cough mixtures by zero-order derivative UV spectrophotometry," African Journal of Pure and Applied Chemistry, vol. 5, pp. 104-110, 2011.

[12] K. Masumoto, Y. Tashiro, K. Matsumoto, A. Yoshida, M. Hirayama, and S. Hayashi, "Simultaneous determination of codeine and chlorpheniramine in human plasma by capillary column gas chromatography," Journal of Chromatography B: Biomedical Sciences and Applications, vol. 381, pp. 323-329, 1986.

[13] M. R. Gomez, L. Sombra, R. A. Olsina, L. D. Martínez, and M. F. Silva, "Development and validation of a capillary electrophoresis method for the determination of codeine, diphenhydramine, ephedrine and noscapine in pharmaceuticals," Farmaco, vol. 60, no. 1, pp. 85-90, 2005.

[14] E. M. Elnemma and M. A. Hamada, "Plastic membrane electrodes for the potentiometric determination of codeine in pharmaceutical preparations," Mikrochimica Acta, vol. 126, no. 1-2, pp. 147-151, 1997.

[15] G. E. Baiulescu and S. D. Popescu, "Determination of codeine, dionin and thebaine by differential pulse polarography," Analytical Letters, vol. 19, no. 5-6, pp. 587-596, 1986. 
[16] J. M. P. J. Garrido, C. Delerue-Matos, F. Borges, T. R. A. Macedo, and A. M. Oliveira-Brett, "Voltammetric oxidation of drugs of abuse: II. Codeine and metabolites," Electroanalysis, vol. 16, no. 17, pp. 1427-1433, 2004.

[17] J.-M. Zen, M.-R. Chang, H.-H. Chung, and Y. Shih, "Determination of codeine in human plasma and drug formulation using a chemically modified electrode," Electroanalysis, vol. 10, no. 8, pp. 536-540, 1998.

[18] Y. Shih, J.-M. Zen, and H.-H. Yang, "Determination of codeine in urine and drug formulations using a clay-modified screenprinted carbon electrode," Journal of Pharmaceutical and Biomedical Analysis, vol. 29, no. 5, pp. 827-833, 2002.

[19] M. H. Pournaghi-Azar and A. Saadatirad, "Simultaneous voltammetric and amperometric determination of morphine and codeine using a chemically modified-palladized aluminum electrode," Journal of Electroanalytical Chemistry, vol. 624, no. 1-2, pp. 293-298, 2008.

[20] M. H. Pournaghi-Azar and A. Saadatirad, "Simultaneous determination of paracetamol, ascorbic acid and codeine by differential pulse voltammetry on the aluminum electrode modified by thin layer of palladium," Electroanalysis, vol. 22, no. 14, pp. 1592-1598, 2010.

[21] M. H. Pournaghi-Azar, S. Kheradmandi, and A. Saadatirad, "Simultaneous voltammetry of paracetamol, ascorbic acid, and codeine on a palladium-plated aluminum electrode: oxidation pathway and kinetics," Journal of Solid State Electrochemistry, vol. 14, no. 9, pp. 1689-1695, 2010.

[22] L'. Švorc, J. Sochr, J. Svítková, M. Rievaj, and D. Bustin, "Rapid and sensitive electrochemical determination of codeine in pharmaceutical formulations and human urine using a borondoped diamond film electrode," Electrochimica Acta, vol. 87, pp. 503-510, 2013.

[23] B. Habibi, M. Abazari, and M. H. Pournaghi-Azar, "Simultaneous determination of codeine and caffeine using single-walled carbon nanotubes modified carbon-ceramic electrode," Colloids and Surfaces B: Biointerfaces, vol. 114, pp. 89-95, 2014.

[24] A. J. Bard and L. R. Faulkner, Electrochemical Methods: Fundamental and Applications, John Wiley \& Sons, New York, NY, USA, 2001.

[25] G. L. Long and J. D. Winefordner, "Limit of detection: a closer look at the IUPAC definition," Analytical Chemistry, vol. 55, no. 7, pp. 712A-724A, 1983. 

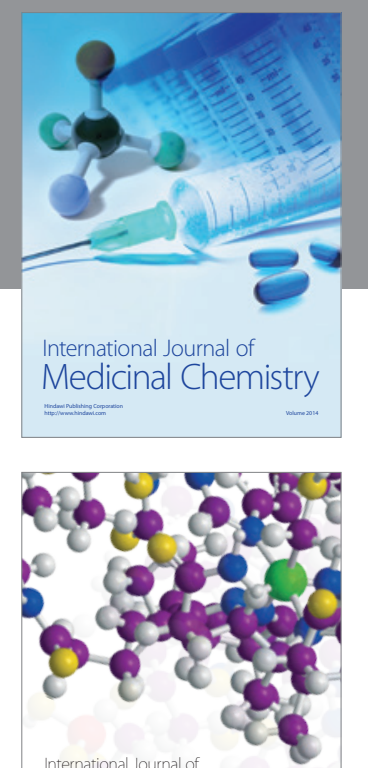

\section{Carbohydrate} Chemistry

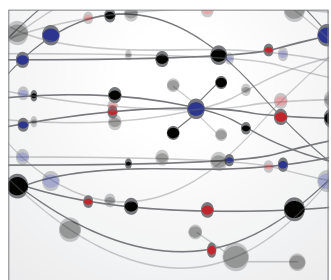

The Scientific World Journal
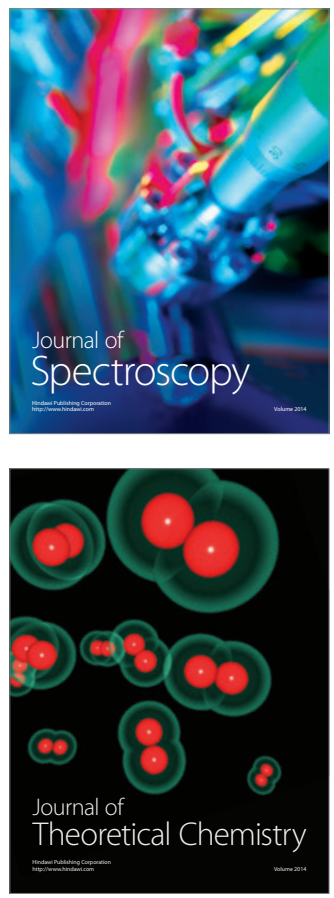
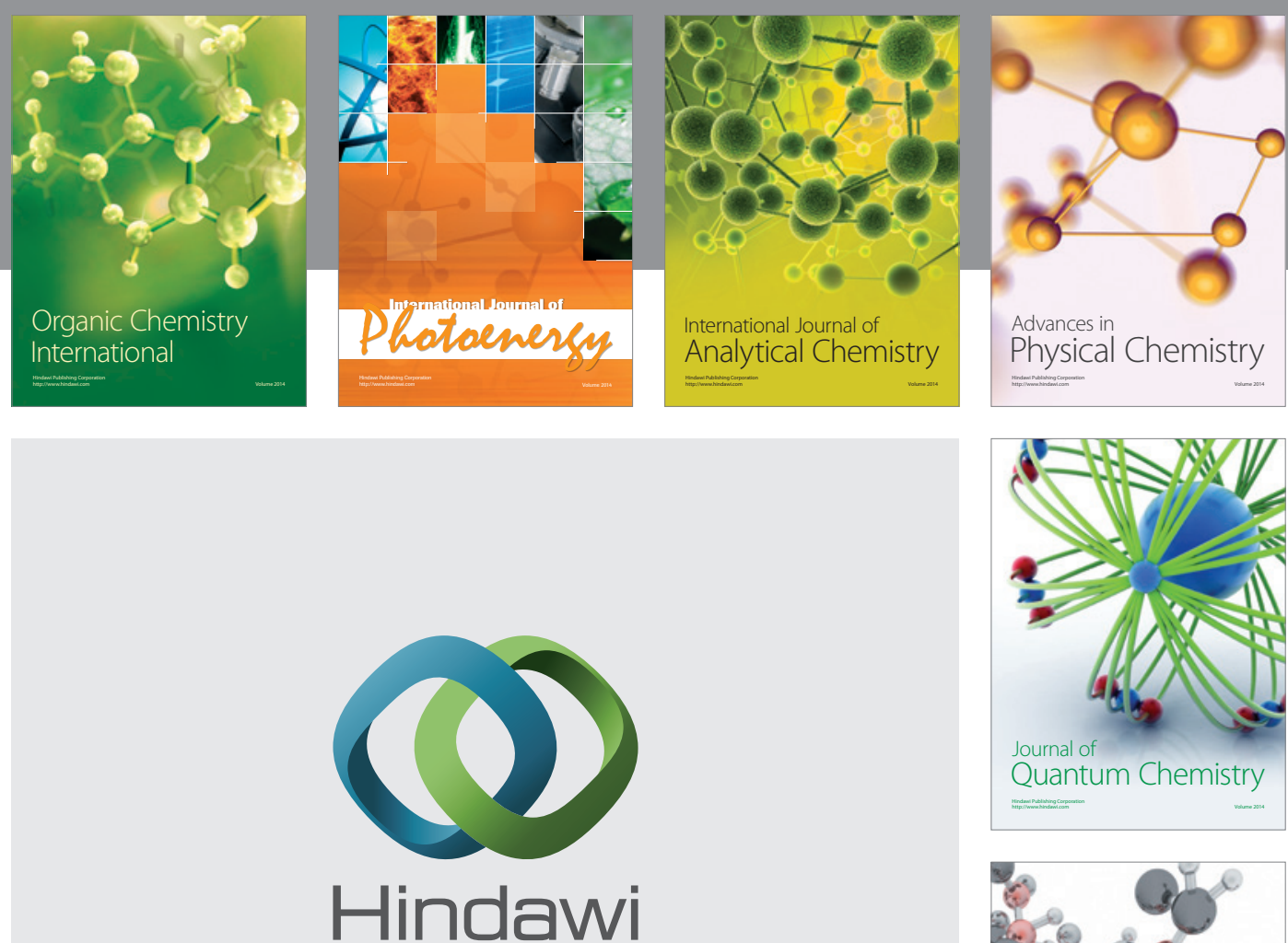

Submit your manuscripts at

http://www.hindawi.com

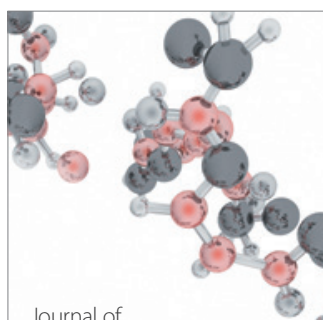

Analytical Methods

in Chemistry

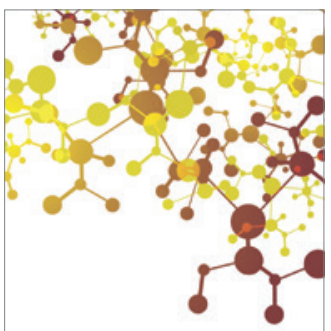

Journal of

Applied Chemistry

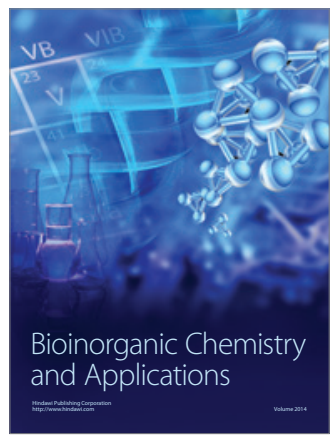

Inorganic Chemistry
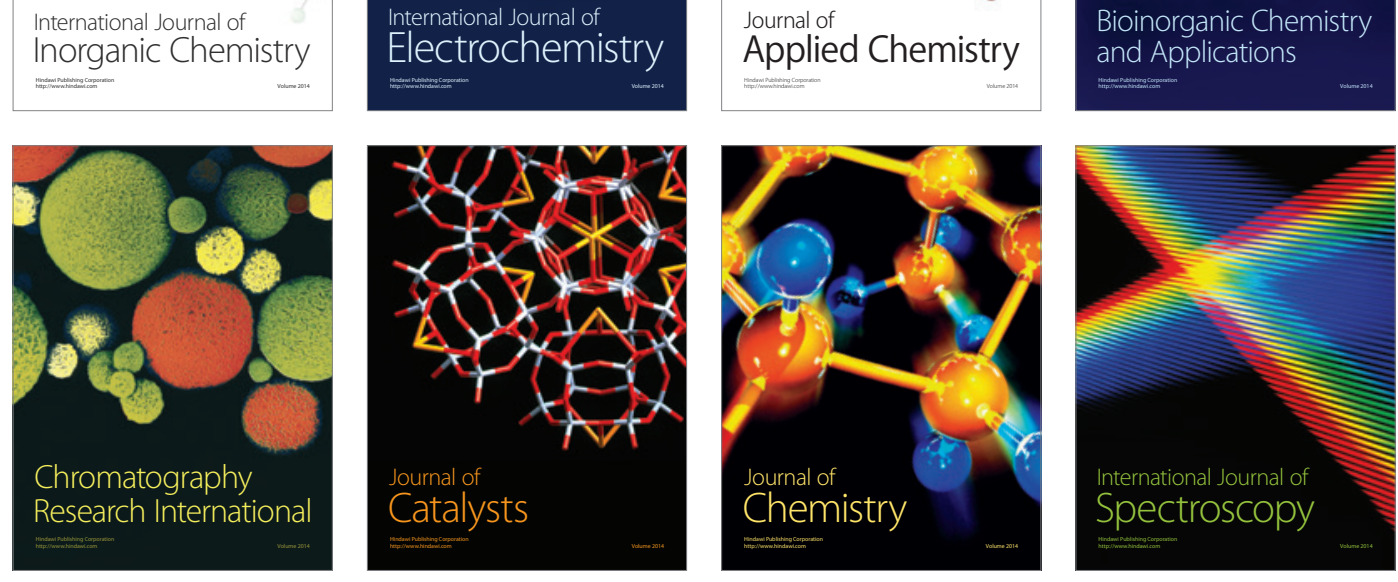